\title{
NOTES
}

\section{NONSMOKING HIRING POLICIES: EXAMINING THE STATUS OF SMOKERS UNDER TITLE I OF THE AMERICANS WITH DISABILITIES ACT OF 1990}

\author{
MARK W. PugsLey
}

\section{INTRODUCTION}

Smoking-related diseases cost the U.S. health care system approximately $\$ 24$ billion annually. Including productivity losses, the cost of smoking is $\$ 52$ billion per year, or $\$ 221$ for every man, woman, and child in the United States. ${ }^{2}$ Many of these costs are inevitably borne by America's businesses, which are paying increasingly more for health care, with little left over for expansion and modernization. In response to concerns about rising insurance costs, employee safety, and growing demands by nonsmokers for a sinoke-free workplace, many employers are adopting policies that restrict or prohibit smoking on the job, and a growing number are taking the additional step of refusing to hire smokers at all. ${ }^{3}$

Smokers who face discrimination may attempt to find refuge under Title I of the Americans with Disabilities Act of 1990 (ADA). ${ }^{4}$ To be covered under the ADA's employment discrimination provisions, a smoker would have to show that he is addict-

1. Centers for Disease Control, U.S. Dep'T of Health \& Hum. Servi., SMOKING AND HEALTH: A NATIONAL STATUS REPORT 40 (2d ed. 1990) [hereinafter SMOKING AND HEALTH]; see also OfFICE OF TECHNOLOGY ASSESSMENT, SMOKING-RELATED DEATHS AND FinANCIAL COSTS 4-5 (1985) [hereinafter SMOKING-RELATED COSTS] (estimating that the total cost of smoking is approximately $\$ 65$ billion per year but noting that the yearly costs could be as high as $\$ 95$ billion or as low as $\$ 38$ billion).

2. SMOKNG AND HEALTH, supra note 1, at 40 . The Office of Technology Assessment estimated that the cost was $\$ 2.17$ for every pack of cigarettes sold. See SMOKINGRELATED COSTS, supra note 1 , at 4-5.

3. See infra Part I.

4. See 42 U.S.C. $\S \S 12101-12213$ (Supp. III 1991). 
ed to nicotine and that this addiction qualifies as a disability that merits protection from employment discrimination.

Nicotine addiction is noticeably missing from the ADA's illustrative list of covered disabilities. ${ }^{5}$ To qualify as disabled under the Act, sinokers would liave to slow that their addiction fits withm the statutory definition of a disability, which would entail proving eitler that their addiction to nicotine substantially inpairs a "major life activity" or that it is "regarded as" impairing a major life activity. ${ }^{6}$ Another approach might be to argue that addiction to nicotine is sufficiently similar to alcoholisin or drug addiction to merit mclusion by analogy. ${ }^{7}$

This Note explores the ADA's definition of disability to determine whether people who are addicted to nicotine should be considered disabled for the purposes of the Act. Part I discusses the probleins that motivate eniployers to discrininate against smokers. Part II provides a brief overview of Title I of the ADA and then exanines whether nicotine addiction falls under the ADA's definition of disability. This Note argues that, although excluding smokers from the workforce may not be the best solution to the problems of smoking in the workplace, addiction to nicotine slould not qualify as a covered disability and concludes that nonsmoking hiring policies are not prohibited under the ADA.

\section{RATIONALES FOR DISCRIMINATION AGAINST SMOKERS}

A growing number of employers are taking measures to control or eliminate smoking in the workplace; sonie have even decided not to hire sniokers at all. ${ }^{8}$ A 1985 survey conducted by the Bureau of National Affairs (BNA) and the American Society for Personnel Administration found that, of the 662 employers responding, more than one-third had restrictive sinoking policies in effect, $2 \%$ were currently developing thein, and another $21 \%$ were considering thein. ${ }^{9}$ Fifteen percent of the companies surveyed

5. Congress specifically included conditions such as multiple sclerosis, cerebral palsy, mental retardation, learning disabilities, HIV infection, drug addiction, and even alcoholism in the ADA's coverage. See H.R. REP. NO. 485, 101st Cong., 2d Sess. 51, reprinted in 1990 U.S.C.C.A.N. 267, 333.

6. See id. at 335; see also infra notes 104-30 and accompanying text.

7. See infra notes $131-36$.

8. See Zachary Schiller et al., If You Light Up on Sunday, Don't Come in on Monday, Bus. WK., Aug. 26, 1991, at 68.

9. BUREAU of NaT'L AFFairs, Where There's SMOKE: PROBlems ANd POLICIES 
either allowed or mandated preferences for nonsmoking job applicants, and $2 \%$ refused to hire smokers at all. ${ }^{10}$ In 1991, BNA updated its survey and found that the number of companies with restrictive policies had grown to $85 \% .^{11}$ Most of the responding companies reported that they had not experienced major enforcement problems, and $69 \%$ said that the policies had improved nonsmokers' morale. ${ }^{12}$

The conflict between interest groups who support smokers' rights and those who promote protection for nonsmokers has proved to be a bitter one. Powerful organizations such as the Tobacco Institute, the American Lung Association, and the American Cancer Society ${ }^{13}$ have developed extensive public relations campaigns to convince employers to adopt smoking policies of one sort or another. ${ }^{14}$

\section{A. The Costs of Smoking to Employers}

An employee who smokes is significantly more expensive to have on the payroll than a nonsmoking employee. ${ }^{15}$ Smokers cause employers to incur extra expenses through higher absentee-

CONCERNING SMOKING IN THE WORKPLACE 12 (1986) [hereinafter WHERE THERE'S SMOKE].

10. Id.; see also Nancy R. Brooks, Some Employers are Saying: 'Smokers Need Not Apply,' L.A. TIMES, Feb. 25, 1993, at D3 (listing several companies that refuse to hire smokers, including Atlanta-based Turner Broadcasting System, which has not hired smokers since 1986, and Health Net, California's second-largest health maintenance organization).

11. Bureau of National Affairs, Bulletin to Management, BNA POL'Y \& PRAC. SERIES, Aug. 29, 1991, at 2.

12. Id. at 8-9.

13. Smaller groups such as the Coalition on Smoking and Health, Americans for Nonsmokers' Rights, and Action on Smoking and Health also have formed to encourage businesses and legislatures to adopt smoking controls. See generally Ronald E. Roel, No Smoking in the City, NEWSDAY, Apr. 4, 1988, at 1 (describing small businesses' efforts to comply with New York's no smoking ordinance).

14. For instance, the Tobacco Institute urges firms to adopt policies that accommodate smokers, rather than ones that impose total bans on smoking. See, e.g., TOBACCO INSTITUTE, SMOKING IN THE WORKPLACE: SOME CONSIDERATIONS (pamphlet, on file with author); R. Lawrence Ashe, Jr. \& Dennis H. Vaughan, Smoking in the Workplace: A Management Perspective, 11 EMPLOYEe REL. L.J. 383 (1986) (authored by two partners at Paul, Hastings, Janofsky \& Walker for the Tobacco Institute); see also Alix M. Freedman \& Laurie P. Cohen, Smoke and Mirrors: How Cigarette Makers Keep Health Question 'Open' Year After Year. WALL ST. J., Feb. 11, 1993, at 1, 6.

15. Total cost estimates range from $\$ 336$ to $\$ 4600$ per smoker per year. See MARION Merell Dow, INC., THE ECONOMIC IMPACT OF SMOKING IN THE WORKPLACE 9 (1991) [hereinafter ECONOMIC IMPACT]; see also WHERE THERE'S SMOKE, supra note 9, at 7. 
ism; ${ }^{16}$ higher health, ${ }^{17}$ fire, ${ }^{18}$ and life insurance costs; ${ }^{19}$ and productivity losses due to poor employee morale and the time consumed by "smoking rituals." 20 Employees who smoke have twice as many on-the-job accidents as nonsmokers. ${ }^{21}$ Property losses due to damage, depreciation, and increased maintenance

16. By one estimate, "smokers are absent from work 50 percent more often than nonsmokers, have twice as many on-the-job accidents, and are 50 percent more likely to be hospitalized than workers who do not smoke." NATIONAL CANCER INSTITUTE \& SMOKING POLICY INSTITUTE, Costs and Benefits of Smoking Restrictions in the Workplace, [hereinafter Costs and Benefits] in SMOKING POLICY: Questions AND ANSwERs, No. 4 [hereinafter SMOKING POLICY] (interview with William Weiss, Albers School of Business, Seattle University). Another study estimated that the excess absenteeism of smokers cost $\$ 330$ extra per smoker per year. See ECONOMIC IMPACT, supra note 15, at 4.

17. One group estimated that smokers submit $\$ 300$ more per year in health insurance claims than do nonsmokers and that heavy smokers are more likely to submit claims for more than $\$ 5000$. See ECONOMIC IMPACT, supra note 15, at 5-6. Recognizing that smoke-free companies may be healthier, many insurers offer them reduced premiums. For example, some fire and casualty companies cut premiums for such companies' employees by $50 \%$. New York Life reduces annual premiums on commercial disability policies by $\$ 150$ per nonsmoking employee, and Blue Cross-Blue Shield of Minnesota offers a $22 \%$ discount on premiums for insured nonsmokers. Costs and Benefits, supra note 16. Some employers have reacted to this discrepancy by charging smokers extra money for health insurance. For instance, in January 1992, Texas Instruments began charging insured employees $\$ 10$ per month for each family member who uses tobacco. See Smoking Brings Higher Health Premiums at TI, STAR TRIBUNE, Jan. 9, 1992, at D2; see also WHERE THERE'S SMOKE, supra note 9, at 9 (discussing one insurance company that banned all smoking on the premises and required all smoking employees to pay $\$ 25$ per month toward health insurance costs).

18. One study estimated the cost of smoking-related fires to be $\$ 340$ million per year in 1986 dollars. See Willard G. MANning et al., The Costs of PoOR Health HaBITS 76 (1991) (citing Bryan R. Luce \& Stuart O. Schweitzer, Smoking and Alcolool Abuse: A Comparison of Their Economic Consequences, 298 NEW ENG. J. MED. 569 (1978)). Another group calculated that each employee who smokes costs his employer annually $\$ 45$ in extra accidental injury and workers' compensation costs, $\$ 45$ in fire, life, and wage continuation policies, and $\$ 5$ to $\$ 10$ in fire losses. See ECONOMIC IMPACT, supra note 15 , at 7 .

19. See Marvin M. Kristein, How Much Can Business Expect to Profit from Smoking Cessation?, 12 Preventive MED. 358, 365 (1983) "(finding that life insurance premiums cost an employer an additional $\$ 20$ to $\$ 33$ per year for each smoker on the payroll). Another study found that smokers have lower retirement and disability costs due to reductions in life expectancy. See MANNING ET AL., supra note 18, at 12.

20. Smoking rituals include lighting a cigarette, smoking, and flicking ashes and can result in lost working time. Some studies estimate that from 8 to 33 minutes of work time is lost per worker per day, or 18.2 days and $\$ 1820$ per year lost for each smoking employee (in 1981. dollars). See ECONOMIC IMPACT, supra note 15, at 9. But see Alfred Vogel, Are Smokers Really Less Productive than Nonsmokers?, LEGIS. POL'Y, Summer 1985, at 6, 6-7 (reporting that the results of a survey of "approximately 1750 first level managers and supervisors" indicated that smoking on breaks does not significantly affect productivity and that occasional smoking while working has little effect on productivity).

21. See ECONOMIC IMPACT, supra note 15 , at 7. 
costs also are exacerbated by employees who smoke..$^{22}$ Smokers may be more listless and inattentive than other workers due to oxygen deprivation, which can affect botl productivity and the quality of an employee's work.

Workplace smokimg has become a sensitive issue with employees and has resulted in a growing number of conflicts between smokers and nonsmokers, ${ }^{23}$ some of which liave ended in costly litigation. ${ }^{24}$ Polls show that a large majority of the American people favors some regulation of smoking im the workplace. ${ }^{25} \mathrm{Al}$ though many of the costs associated with smoking in the workplace may be rehieved by restrictive smoking policies, others, such as increased health care and absenteeism costs, can be controlled only by eliminating smokers from the workforce completely.

The direct cost of smoking is not the only motivation for employers to refuse to hire smokers. Companies often formulate smoking policies in response to employee complaints about smoking $^{26}$ and to avoid potential liability for illnesses caused by environmental tobacco smoke (ETS). ${ }^{27}$ Some occupations expose workers to hazardous airborne substances such as asbestos, coal dust, or cotton dust. Cigarette smoke acts synergistically with many of these substances to exacerbate their harmful effects. ${ }^{28}$ For instance, smokers who work with asbestos are fifty times more likely to develop lung cancer than asbestos workers who do not

22. A survey of 2000 companies that had adopted no smoking policies found that $60 \%$ reported significant reductions in cleaning and maintenance costs. Id. at 8 .

23. See, e.g., WHERE THERE'S SMOKE, supra note 9, at 27; Mark A. Rothstein, Refusing to Employ Smokers: Good Public Health or Bad Public Policy?, 62 NOTRE DAME L. REv. 940, 953 (1987); David B. Ezra, Note, Smoker Battery: An Antidote to SecondHand Smoke, 63 S. CAL. L. REV. 1061, 1062 (1990).

24. See, e.g., Richardson v. Hennly, 434 S.E.2d 772 (Ga. Ct. App. 1993). In Richardson, a former employee filed suit against a savings and loan association and a co-employee, alleging battery and intentional infliction of emotional distress after the co-employee "intentionally smoked around [the plaintiff] to annoy her." Id. at 774. The court held that intentionally directing pipe smoke at another could indeed constitute battery. $I d$. at 775.

25. A 1985 Gallup poll found that $88 \%$ of all respondents, including $80 \%$ of smokers, said that some policy should be in force. Eighty percent said that smoking should be restricted to certain areas, and $76 \%$ of smokers agreed. Few of those polled, however, supported a total ban on smoking in the workplace. See WHERE THERE's SMOKE, supra note 9 , at 8 .

26. See id. at 13.

27. See infra notes $37-57$ and accompanying text.

28. See Rothstein, supra note 23 , at 951. 
smoke. ${ }^{29}$ This differential increases to ninety times with asbestos workers who smoke more than a pack of cigarettes daily. ${ }^{30} \mathrm{~A}$ heavily exposed asbestos worker who also smokes more than a pack per day has a $5000 \%$ greater risk of developing lung cancer than a person who neither smokes nor works with asbestos. ${ }^{31}$ Significantly, even smoking outside of work is likely to produce these synergistic effects. Thus, industries where employees are exposed to these kinds of risks there is a particularly strong motive for hiring only nonsmokers.

Some states provide by statute that firefighters who have heart attacks or develop lung cancer or pulmonary diseases are generally entitled to workers' compensation when there is a jobrelated cause-even if the condition would not have developed but for the employee's smoking. ${ }^{32}$ Smoke inhalation is significantly more hazardous to smokers than to nonsmokers. ${ }^{33}$ The risk of liability has prompted many fire departments to adopt nonsmoking policies for employees both on and off the job.

A fire department in Oklahoma City adopted such a policy in an effort to maintain a healthy workforce and reduce workers' compensation costs. A firefighter trainee who was dismissed for smoking on his lunch break challenged the policy. In Grusendorf v. City of Oklahoma City, ${ }^{34}$ the U.S. Court of Appeals for the Tenth Circuit held that the nonsmoking rule did not violate due process because, although the off-duty smoking ban may have infringed Grusendorf's liberty interest under the Fourteenth Amendment, it had a rational relationship to the legitimate state purpose of promoting the health and safety of the employees. ${ }^{35}$ Although no reported cases have examined the issue, it seems likely that, in hight of the Environmental Protection Agency's

29. Id.; see also Smoking and the Blue-Collar Work Force, in SMOKING POLICY, supra note 16, No. 10 (interview with Donald Shopland, representative of the Smoking, Tobacco, and Cancer Program's National Cancer Institute).

30. SMOKING POLICY, supra note 16 , No. 10.

31. Id.

32. See Rothstein, supra note 23 , at 952 (discussing the statutory creation by over half the states of an irrebuttable presumption that cardiovascular or respiratory impairment suffered by a firefighter is work-related); see also infra notes 70-72 and accompanying text.

33. Id. at $952-53$.

34. 816 F.2d 539 (10th Cir. 1987).

35. Id. at 543 . 
(EPA) report on the dangers of ETS, ${ }^{36}$ courts could extend this reasoning to uphold other smoking policies that are rationally related to promoting the health and safety of employees.

\section{B. Environmental Tobacco Smoke}

Clear evidence shows that ETS, also known as passive or involuntary smoking, presents a significant health risk to nonsmokers. ${ }^{37}$ In January 1993, the EPA released a massive study that branded secondary tobacco smoke a class A human carcinogen that causes $20 \%$ of all lung cancers in the United States. ${ }^{38}$ In 1986, then-U.S. Surgeon General C. Everett Koop issued a report on ETS that concluded, inter alia, that involuntary smoking causes diseases, including lung cancer, in healthy nonsmokers and that because of constant air circulation, the simple separation of smokers and nonsmokers within the same airspace may reduce, but does not eliminate, nonsmokers' exposure to ETS, even when filtering devices are used. ${ }^{39}$ One scientist has even asserted that mhaling ETS may be a greater risk of cancer for the general population than all other agents in the environment. ${ }^{40}$ To date, the

36. See infra Section I(B).

37. According to the American Lung Association, tobacco smoke contains about 4000 chemicals, including 200 known poisons such as DDT, arsenic, formaldehyde, and carbon monoxide. Sidestream smoke, which goes directly into the air from the burning tobacco and is inhaled by nonsmokers, actually has higher concentrations of some harmful compounds than the mainstream smoke inhaled by the smoker. Studies show that sidestream smoke contains twice as much tar and nicotine and three times as much carbon monoxide. AMERICAN LUNG ASSOCIATION, FACTS ABOUT SECONDHAND SMOKE 2 (1988); see also NATIONAL CANCER INSTITUTE, INVOLUNTARY SMOKING (1990); Emmet W. Lee \& Gilbert E. D'Alonzo, Cigarette Smoking, Nicotine Addiction, and its Pharmacologic Treatment, 153 ARCHIVES INTERNAL MED. 34, 35 (1993) (finding that the risk of lung cancer from passive smoking is more than 100 times greater than the estimated effect of 20 years' exposure to asbestos while living or working in an asbestos-contaminated building). But see WHERE THERE'S SMOKE, supra note 9, at 5-6 (noting that the tobacco industry disputes many of these findings).

38. Office OF Res. \& DEV., U.S. ENVTL. PROTECTION AGENCY, RESPIRATORY HEALTH EFFECTS OF PASSIVE SMOKING 2-2 (1992) (finding that the risks associated with ETS are a substantial public health concern); see also Rudy Abramson, EPA Officially Links Passive Smoke, Cancer, L.A. Times, Jan. 8, 1993, at A26; EPA Attributes 3,000 Non-Smoker Lung Cancer Deaths Annually to Secondhand Smoke, HEALTH NEws DaILY, Jan. 8, 1993, at 4.

39. See Report of the SuRgeon General, U.S. Dep'T of Health \& Hum. SeRvS., THE HEALTH CONSEQueNCES OF INVOLUNTARY SMOKING 7 (1986); see also U.S. Dep'T of Health \& HuM. SERvs., Major local SMOKIng ORdinances in the UNITED STATES 1 (1989) [hereinafter LOCAL ORDINANCES].

40. See The Health Effects of Environmental Tobacco Smoke, in SMOKING POLICY, 
Occupational Safety and Health Administration (OSHA) has shied away from regulating secondhand tobacco smoke, but has already received more than 1200 comments and studies on the ETS problem since it issued a request for information on indoor air issues in $1991 .^{41}$ It is expected to issue an advance notice of expected rulemaking on ETS in $1994 .{ }^{42}$

Public awareness of the serious health threat ETS poses will likely initiate much more righteous indignation-and litigation-aimed at smokers. One interesting, and perhaps illustrative, incident occurred in May 1993 in a Baltimore County restaurant. Deborah Jane Lowenstein was sitting in the smoking section, exercising her right to smoke, when another patron asked her to put out her cigarette. The ensumg argument culminated with one man (a 47-year-old lawyer) allegedly "smacking her on the forehead like an old-time faith healer and saying, 'Heal! Heal!' while another was tying her belt loops to the chair." ${ }^{43}$ Lowenstein filed battery charges agaimst both men. Her attorney, Craig M. Kadish, likened the incident to "the resurgence of Nazism in Europe and ethnic cleansing in Bosnia." 44

Potential legal hability provides employers with another strong incentive to eliminate ETS from the workplace. Some courts have held that employers have a common law duty to provide a smokefree working environment for the comfort and safety of nonsmoking employees. ${ }^{45}$ The first case of this kind was Shimp $v$.

supra note 16, No. 1 (quoting David M. Burns, M.D., senior scientific editor of the 1986 Surgeon General's report, based on estimates by the National Academy of Sciences and the EPA); see also Kyle Steenland, Passive Smoking and the Risk of Heart Disease, 267 JAMA 94, 99 (1992) (concluding that ETS is responsible for 35,000 to 40,000 heart disease deaths among current nonsmokers annually and that the lifetime heart disease risk from ETS is far greater than that used to determine environmental limits for other toxins).

41. Special Report: OSHA '94: Seeking Redefined Mission, Revitalization of Existing Authorities, 23 O.S.H. Rep. (BNA) No. 32, at 963, 972-73 (Jan. 12, 1994).

42. Id. But see Harvey M. Sapolsky, The Political Obstacles to the Control of Cigarette Smoking in the United States, 5 J. HEALTH POL. POL'Y \& L. 277 (1980) (noting that any government control of tobacco would face serious political obstacles).

43. Fern Shen, Maryland Woman Alleges Attack for Smoking in Restaurant, WASH. POST, May 22, 1993, at D1.

44. Id.

45. See, e.g., Smith v. Western Elec. Co., 643 S.W.2d 10, 13 (Mo. Ct. App. 1982) (finding allegations of workplace exposure to tobacco smoke sufficient to state a claim for breach of employer's common law duty to provide a safe workplace); McCarthy v. Department of Social \& Health Servs., 759 P.2d 351 (Wash. 1988) (holding that an employee stated a common law tort claim when she alleged that her employer negligently 
New Jersey Bell Telephone Co. ${ }^{46}$ decided in 1976. The court held that a secretary who was sensitive to cigarette smoke had a common law right to a safe working environment and was entitled to an injunction forcing her employer to restrict smoking in her work area. ${ }^{47}$ Cases such as this should be much easier to win today in light of the voluminous new scientific evidence documenting the dangers of ETS to all employees. ${ }^{48}$

Courts also have held that employees who are allergic or hypersensitive to tobacco smoke are "handicapped" under the Rehabilitation Act of $1973 .{ }^{49}$ For instance, in Vickers v. Veterans Administration, ${ }^{50}$ the court held (1) that an employee who worked in a smoke-filled environment and was unusually sensitive to tobacco smoke qualified for protection because he was limited in his capacity to work; and (2) that working constituted a "major life activit[y]." 51 This decision may prompt more employers to eliminate smoking from the workplace to avoid potential tort liability and increased disability ${ }^{52}$ and unemployment insurance ${ }^{53}$ claims.

required her to work in a smoke-filled office, which resulted in her contracting a chronic obstructive pulmonary disease). But see Gordon v. Raven Sys. \& Research, Inc., 462 A.2d 10,15 (D.C. 1983) (holding that an employer did not have a common law duty to provide a smoke-free environment for an employee who was particularly sensitive to cigarette smoke and who refused to work in an area occupied by smokers).

46. 368 A.2d 408 (N.J. Super. Ct. Ch. Div. 1976).

47. Id. at $409-10,416$.

48. See supra notes $37-40$ and accompanying text.

49. 29 U.S.C. $\$ \S 701,793-794$ (1988); see infra notes 77-78 and accompanying text (discussing the use of the Rehabilitation Act of 1973 in interpreting the ADA).

50. 549 F. Supp. 85 (W.D. Wash. 1982).

51. Id. at 87; see also County of Fresno v. Fair Employment \& Hous. Comm'n, 277 Cal. Rptr. 557 (1991) (holding that employees who are hypersensitive to tobacco smoke due to respiratory illnesses are handicapped under the Rehabilitation Act). But see GASP v. Mecklenburg County, 256 S.E.2d 477 (N.C. Ct. App. 1979) (rejecting plaintiffs' claim that their sensitivity to smoking constituted a handicap under the Rehabilitation Act); $c f$. Harmer v. Virginia Elec. \& Power Co., 831 F. Supp. 1300 (E.D. Va. 1993) (holding that the plaintiff was not entitled to protection under the ADA because he failed to establish that the employer's accommodations were insufficient and because positive evaluations proved he was still able to perform the essential functions of his job adequately, despite his sensitivity to cigarette smoke).

52. See, e.g., Parodi v. Merit Sys. Protection Bd., 702 F.2d 743 (9th Cir. 1982) (holding that a federal employee who was hypersensitive to cigarette smoke established a prima facie case for entitlement to disability benefits by showing inability to continue working).

53. See, e.g., McCrocklin v. Employment Dev. Dep't, 205 Cal. Rptr. 156 (Ct. App. 1984) (stating that an employee had good cause for leaving his job because of a reasonable fear of harm to his health and safety from the work environment). 
Owners of bars and restaurants could be particularly vulnerable to lawsuits in light of a recent study published in the Journal of the American Medical Association. The study found that the level of secondhand sinoke in restaurants is up to two times higher than that found in offices and 1.5 times higher than that found in homes with at least one smoker. Bars are even worse, containing levels of ETS up to 6.1 times higher than in offices and 4.5 times higher than in hoines with at least one sinoker. The study concluded, based on these figures, that restaurant workers may face a $50 \%$ higher risk of contracting lung cancer than the general population. $^{54}$

Banming sinoking froin some work areas or segregating smokers and nonsinokers will not completely solve the ETS problem, however. To eliminate ETS pollution from the workplace entirely, smoking areas must have separate ventilation and circulation systems; otherwise, toxins will be constantly recirculated throughout the building. ${ }^{55}$ Expensive filters can eliminate only some of the harmful particles from the air, leaving the gases that contain most of the irritants. ${ }^{56}$ In most cases, companies find it financially prohibitive to install new ventilation systems in individual offices or in smoking areas within the building. ${ }^{57}$

Failing to provide smoking facilities at all, however, will exacerbate productivity losses caused by employees who sinoke. Sinokers take frequent breaks; requiring thein to travel outside the building or to a separate building can further increase time lost. ${ }^{58}$ Clearly, maintaining a smoke-free workplace is burdensoine, particularly for small coinpanies with few financial resources. Instituting nonsmoking hiring policies, and thereby gradually eliminating smokers froin the workforce, is understandably seen as an attractive alternative that can decrease productivity losses.

54. Michael Siegel, Involuntary Smoking in the Restaurant Workplace, 270 JAMA 490 (1993).

55. See Smoking in the Workplace: Ventilation, in SMOKING Policy, supra note 16, No. 5 (interview with James L. Repace, Physicist for the EPA's Indoor Air Program, U.S. Environmental Protection Agency).

56. Id.

57. The burden on larger corporations and companies that are building new facilities, however, may not be great enough to qualify for the ADA's undue hardship defense. See infra subsection II(C)(2).

58. See WHERE THERE'S SMOKE, supra note 9, at 7 (citing one report that estimated that employees who leave the worksite to smoke cost $\$ 309.5$ million per year in productivity losses, or $\$ 867$ per employee-assuming only two, 10-minute breaks a day). 


\section{Local Legislative Responses}

Some state legislatures have responded to the growing trend of establishing hiring preferences for nonsmokers by passing laws that prohibit employers from basing employment-related decisions on workers' off-duty activities. ${ }^{59}$ These statutes attempt to curb so-called lifestyle discrimination. ${ }^{60}$ Without these prohibitions, it is argued, businesses potentially could force employees to lose weight, lower their blood pressure, or even refrain from hang gliding. ${ }^{61}$ Although this argument may be persuasive with respect to some intrusive restrictions, most smoking controls are directly linked to the legitimate business needs of maintaming a productive workforce and protecting the health of nonsmoking employees. Laws that do not allow employers latitude in this basic realm of business management can be detrimental to the competitiveness of businesses.

Most of these legislative actions are hardly the result of a spontaneous uprising to champion smokers' rights. Rather, they have been initiated and actively backed by the Tobacco Institute. ${ }^{62} \mathrm{~A}$ few labor umions have supported the enactment of these statutes, ${ }^{63}$ but most have been unwilling to take a definite stand

59. See Christine Woolsey, Off-Duty Conduct: None of Employer's Business, Bus. INS., Feb. 17, 1992, at 10 (noting that such laws have passed in 21 states); see also Barbara Franklin, Employees' Rights: New Law Protects "Legal Activities" of Workers, N.Y. L.J., Dec. 17, 1992, at 5 (discussing a New York law that makes it illegal for a company to refuse to hire anyone based on "smok[ing], drink[ing], or engag[ing] in other legal activities outside of work").

60. James Bone, Too Close for the Company, THE TIMEs (LONDON), April 27, 1992, at LT4. See generally Marvin Hill, Jr. \& Emily Delacenserie, Procrustean Beds and Draconian Choices: Lifestyle Regulations and Officious Intermeddlers-Bosses, Workers, Courts, and Labor Arbitrators, 57 Mo. L. REV. 51 (1992) (discussing the legal treatment of employers' attempts to regulate employees' lifestyles).

61. See Bone, supra note 60 , at LT4 (noting that some companies have refused to hire people who ride motorcycles or hang glide because of the potential impact these activities have on employer-provided health insurance premiums); Dennis J. McGrath, New Laws Give More Rights to Smokers, STAR TR1B., May 17, 1992, at A1 (quoting advocates for the Tobacco Institute and the American Civil Liberties Union); Paula Span, Smokers' New Hazard: No Work, WASH. POST, Nov. 12, 1991, at A1 (noting examples of restrictions placed on employee lifestyle decisions by employers).

62. LOCAL ORDINANCES, supra note 39, at vi; McGrath, supra note 61, at A1; Janny Scott, Tobacco Firms Mimic Grass-Roots Foes, Study Says, L.A. TIMES, Oct. 16, 1991, at A3.

63. See WHERE THERE's SMOKE, supra note 9, at 25-29 (reporting that in 1986 the AFL-CIO Executive Council opposed both employer-mandated and legislated smoking restrictions). 
on the issue, fearing disputes between smoking and nonsmoking members. ${ }^{64}$ All unions, however, strongly support restrictions that are directly related to worker safety. ${ }^{65}$

The Tobacco Institute long has exhorted smokers to fight local government intrusions into the right to smoke through grassroots smokers' rights movements. ${ }^{66}$ Such efforts have been only margimally successful, perhaps in part because most smokers are not particularly proud of their habit and would like to quit. A 1991 Gallup poll found that $76 \%$ of smokers would give up smoking if they could. ${ }^{67}$

In contrast to laws that prohibit discrimination against smokers, statutes in forty-four states protect nonsmokers, ${ }^{68}$ and nearly 400 local ordinances have been enacted to this end. ${ }^{69}$ In addition, many states have added "heart and lung" provisions to their workers' compensation laws to protect employees exposed to harmful smoke and gases on the job. ${ }^{70}$ These provisions generally create an irrebuttable presumption that the causes of cardiovascular and respiratory diseases are work-related and thus must be covered by workers' compensation. ${ }^{71}$ In response to such legislation, some fire and police departments have imposed a ban on hiring smokers in an effort to reduce potential workers' compensation and hability costs. ${ }^{72}$

64. Id. at 27.

65. Id. at 25. This statement might call into question union neutrality on the smoking issue, particularly in light of recent revelations concerning the dangers of ETS to nonsmoking employees. See supra notes $37-40$ and accompanying text (discussing these dangers). at 7 .

66. See Paula Span, A New Hazard for Smokers, Houston CHRON., Dec. 13, 1991,

67. This national telephone survey of 2014 adults asked the following question: "All things considered, would you like to give up smoking cigarettes, or not?" Seventy-six percent said yes, $22 \%$ said no, and $2 \%$ had no opinion. ROPER CENTER FOR PUBLIC OPINION RESEARCH, UNIV. OF CONN. (1991), available in WESTLAW, Poll database.

68. Nancy A. Rigotti \& Chris L. Poshos, No-Smoking Laws in the United States, 266 JAMA 3162 (1991).

69. See LOCAL ORDINANCES, supra note 39, at vi. The local ordinances tend to be more specific than state laws. For instance, $75 \%$ mandate that employers address the issue of smoking in the workplace. These laws do not necessarily conflict with lifestyle discrimination prohibitions.

70. See Rothstein, supra note 23 , at $952-53$ (referring to statutes that limit protection to firefighters).

71. Id.

72. See, e.g., Brooks, supra note 10 , at D3. 


\section{Title I of the Americans with Disabilities ACT}

The growing trend of hiring nonsmokers exclusively has prompted some commentators to advocate refuge for smokers under the sweeping provisions of the $\mathrm{ADA} .^{73}$ However, nicotine addiction does not qualify under the statutory definition of disability because it neither substantially limits a major life activity nor is generally regarded as doing so. Even if courts ultimately determine that smokers are disabled under the ADA, some employers may still be able to justify discriminatory hiring practices under the Act's defenses.

\section{A. An Overview of the Act}

The Americans with Disabilities Act of $1990^{74}$ was enacted to "provide a clear and comprehensive national mandate to end discrimination against individuals with disabilities and to bring those individuals into the economic and social mainstream of American life. ${ }^{, 75}$ Congress found that disabled people occupy a decidedly disadvantaged position in society, both socially and economically, and that this status is primarily the result of purposeful discrimination, rather than an inevitable consequence of their physical or mental limitations. ${ }^{76}$ The ADA is intended to bolster the provisions of the Rehabilitation Act of $1973,{ }^{77}$ from which it borrows much of its language. Commentators differ, however, as

73. See, e.g., Jimmy Goh, Note, "Smokers Need Not Apply": Challenging Employment Discrimination Against Smokers Under the Americans with Disabilities Act, 39 U. KAN. L. REV. 817 (1991) (arguing that the ADA prohibits employers from discriminating against smokers in hiring decisions); Christina Grasso, Note, Are Employers Who Refuse to Hire Smokers Discriminating Within the Meaning of the Americans with Disabilities Act of 1990?, 66 ST. JoHN'S L. REv. 1109 (1993) (concluding that an addicted smoker may be considered disabled under the ADA but that it remains to be seen whether he will receive its benefits and protections).

74. 42 U.S.C. $\S \S 12101-12213$ (Supp. III 1991).

75. H.R. REP. No. 485, 101st Cong., 2d Sess. 23, reprinted in 1990 U.S.C.C.A.N. 267, 446.

76. Id. at 448.

77. 29 U.S.C. $\$ \S 701,793-794$ (1988). For a more complete discussion of the relationship between the Rehabilitation Act and the ADA, see Lowell P. Weicker, Jr., Historical Background of the Americans with Disabilities Act, 64 TEMP. L. REV. 387 (1991); see also Jeffrey Higginbotham, The Americans with Disabilities Act, 12 HAMLINE J. PUB. L. \& POL'Y 217, 219 n.12 (1991) (discussing the significance of the Rehabilitation Act in interpreting the ADA). 
to how much weight courts should give legal precedent under the Rehabilitation Act when interpreting the ADA. ${ }^{78}$

Title $\mathrm{I}$ of the ADA prohibits discrimination against qualified disabled individuals with respect to any term, condition, or privilege of employment. ${ }^{79}$ This title went into effect on July 26,1992 , two years after the ADA was passed.$^{80}$ For the first two years, the ADA regulated businesses employing twenty-five or more employees; in 1994, its scope extends automatically to companies with fifteen or more employees. ${ }^{81}$

A key component of Title $I$ is the term "qualified individual with a disability," 82 which, according to the legislative history, means someone with a disability who, with or without reasonable accommodation, can perform the essential functions of a desired position. ${ }^{83}$ The objective of this language is to ensure that employment decisions are made based on qualifications that are unrelated to the existence or consequences of a disability. ${ }^{84}$ Employers are given some latitude to determine the essential functions of a job, but courts also consider evidence such as written job descriptions and the amount of time spent on particular tasks. ${ }^{85}$

78. See, e.g., Weicker, supra note 77, at 387 (arguing that the Rehabilitation Act should be used in interpreting the ADA); see also Jeffery O. Cooper, Overcoming Barriers to Employment: The Meaning of Reasonable Accommodation and Undue Hardship in the Americans with Disabilities Act, 139 U. PA. L. REV. 1423, 1426 (1991). Cooper asserts that

[a]lthough Congress clearly relied upon the regulations implemented under the Rehabilitation Act in drafting the ADA, the ADA's statutory language and extensive legislative history suggest that Congress intended to modify the Rehabilitation Act's approach to employment discrimination in subtle but significant ways .... [C]ourts must not apply Rehabilitation Act precedent to the ADA uncritically, but instead must recognize the ways in which Congress's expressed intent differs from the approach taken by the courts under section 501, and Id. especially section 504, of the Rehabilitation Act.

79. 42 U.S.C. \& 12112(a) (Supp. III 1991).

80. See Americans with Disabilities Act $\S 108$, Pub. L. No. 101-336, 104 Stat. 327, 337 (1990).

81. 42 U.S.C. \& $12111(5)(\mathrm{A})$.

82. Id. § 12112(a).

83. See H.R. REP. No. 485,101 st Cong., $2 \mathrm{~d}$ Sess. 55, reprinted in 1990 U.S.C.C.A.N. 267, 337.

84. Id.

85. The EEOC's regulations, authorized under $\S 12116$ of the ADA, provide an extensive list of criteria to determine whether a particular function is essential:

(n) Essential Functions-(1) In general. The term essential functions means the fundamental job duties of the employment position the individual with a disability holds or desires. The term "essential functions" does not include the marginal functions of the position. 
The definition of disability in the ADA is critical to the discussion in this Note. Disabihty is defined as: "(A) a physical or mental impairment that substantially limits one or more of the major life activities of such individual; (B) a record of such impairment; or (C) being regarded as having such an impairment." ${ }^{36}$

The ADA requires that employers make reasonable accommodations to the known limitations of employees with disabilities, unless such accommodations would impose an undue financial burden on the business. ${ }^{87}$ Accommodations may include installing ramps or elevators for better accessibility, allowing for job restructuring or modified work schedules, or purchasing new equipment. The required accommodations will vary based on the individual's needs in each case. ${ }^{88}$

\section{B. Nicotine Addiction and the ADA's Definition of Disability}

In its initial consideration of the ADA, Congress stated that some 43 million Americans have at least one physical or mental disability. ${ }^{89}$ Congress also found that people with disabilities, as a group, occupy an inferior status in society and are severely disadvantaged socially, vocationally, economically, and educationally. ${ }^{90}$

(2) A job function may be considered essential for any of several reasons, including but not limited to the following:

(i) The function may be essential because the reason the position exists is to perform that function;

(ii) The function may be essential because of the limited number of employees available among whom the performance of that job function can be distributed; and/or

(iii) The function may be highly specialized so that the incumbent in the position is hired for his or her expertise or ability to perform the particular function.

29 C.F.R. § $1630.2(\mathrm{n})(1)-(2)(1993)$.

86. 42 U.S.C. $\S 12102(2)$ (Supp. III 1991). The second and third alternatives are conditioned on having a "record of" or "being regarded as having" the type of impairment that satisfies the first definition.' See Mark D. Laponsky, Defining "Disability": $A$ Look at the Term Within the Context of the Americans with Disabilities Act, 30 FED. B. NEwS \& J. 44 (1992).

87. 42 U.S.C. $\$ 12112(\mathrm{~b})(5)$. For a more complete discussion of these terms, see Margaret E. Stine, Comment, Reasonable Accommodation and Undue Hardship Under the Americans With Disabilities Act of 1990, 37 S.D. L. REV. 97 (1992).

88. See H.R. REP. No. 485, 101st Cong., 2d Sess. 39-40, reprinted in 1990 U.S.C.C.A.N. 267, 461-63.

89. 42 U.S.C. $\S 12101(a)(1)$ (Supp. III 1991).

90. Id. § 12101(a)(2)-(3). 
Smokers, on the other hand, are not so disadvantaged. The estimated 46.8 million Americans who currently smoke, as well as the 43.4 million former smokers, ${ }^{91}$ occupy every socioeconomic and educational level in America. Although the percentage of smokers is shghtly higher among the lower socioeconomic segments of society, ${ }^{92}$ no experts contend that this statistic is due to discrimination based solely on addiction to nicotine. ${ }^{93}$ Smokers are neither severely disadvantaged nor discriminated against to such an extent that the passage or application of federal legislation to resolve their plight is appropriate. ${ }^{94}$

Unfortunately, Congress did not see fit to resolve this troublesome issue. Smoking is mentioned only once in the ADA.

Nothing in this chapter shall be construed to preclude the prohibition of, or the imposition of restrictions on, smoking in places of employment covered by subchapter I of this chapter, in transportation covered by subchapter II or III of this chapter, or in places of public accommodation covered by subchapter III of this chapter. ${ }^{95}$

This provision is inconclusive as to whether the drafters intended to include smoking as a covered disability in the ADA. The issue was intentionally left ambiguous. This ambiguity is not surprising given the delicate balance of interests that was required to pass the legislation; an explicit inclusion or exclusion of smoking would have mobilized several powerful special interest groups and might have prevented the legislation's passage.

The legislative history of the ADA lists a variety of conditions that qualify as physical or mental impairments. These include, inter alia, cerebral palsy, cancer, HIV infection, learning disabilities, drug addiction, and alcoholism. ${ }^{96}$ Physical characteristics, such as

91. See Public Health Serv., Dept. of Health \& Hum. Servs., Smoking and HEALTH 21 (1992).

92. See WHERE THERE'S SMOKE, supra note 9, at 8.

93. Some have argued, however, that such a causal link could arise if the practice of not hiring smokers became widespread. See, e.g., Rothstein, supra note 23, at 960 . Despite this possibility, courts would be hard-pressed to find legislative history or sound policy reasons supporting the treatment of smokers as a protected class. See infra text accompanying notes $154-56$.

94. In fact, a 1986 Robert Half poll of Fortune 1000 executives found that $22 \%$ of vice presidents and personnel directors smoke and that $61 \%$ are former smokers. These executives estimated that $14 \%$ of top managers, $19 \%$ of middle managers, and $24 \%$ of personnel smoke. See WHERE THERE'S SMOKE, supra note 9, at 9.

95. 42 U.S.C. \& 12201(b) (Supp. III 1991) (emphasis added).

96. See H.R. REP. No. 485, 101st Cong., 2d Sess. 51 (1990), reprinted in 1990 
eye color, and environmental, cultural, and economic disadvantages are not included..$^{97}$ Although drug addiction is covered, the use of illegal drugs is explicitly excluded. ${ }^{98}$ Nicotine is undoubtedly both legal and addictive, ${ }^{99}$ but nicotine addiction does not therefore automatically fit the ADA's definition of disability.

To qualify for coverage under the ADA's definition of disability, a smoker would have to demonstrate that his habit goes beyond inere social smoking and ainounts to a dependence on, or addiction to, nicotine. ${ }^{100}$ The burden of proving such a condition presents a host of troublesoine issues for employers, courts, and the inedical community. ${ }^{101}$ For instance, employers and courts might require certification that the sinoker has tried, and failed, to kick the habit through an accredited cessation progranı. ${ }^{102}$ Doctors would be asked to certify the addiction without treating it, despite knowing that effective treatınents are readily available. Studies show that the vast majority of sinokers want to quit, ${ }^{103}$ yet a requirement of certification might create a disincentive to do so if it ineant losing special status under the Act.

Under the statutory definition, a disability is an impairment that "substantially limit[s] one or more of the inajor life activities."104 Major life activities include "caring for one's self, per-

U.S.C.C.A.N. 267, 333.

97. Id. at $333-34$.

98. Id. at 333 .

99. In 1988, the Surgeon General's report on the health consequences of smoking concluded that cigarette smoking and tobacco use met the Department of Health and Human Services' criteria for drug dependency. See REPORT OF THE SURGEON GENERAL, Dep'T of Health \& Hum. Servis., The Health Consequences of SMOKING: NicoTINE ADDICTION iv-v, 215 (1988); Lee \& D'Alonzo, supra note 37, at 38.

100. Courts defining drug addiction for the purpose of coverage under the Rehabilitation Act have held that the mere use of drugs, as distinguished from addiction, is not classified as a handicap under $\S 504$. See, e.g., Burka v. New York City Transit Auth. 680 F. Supp. 590, 601 (S.D.N.Y. 1988).

101. For a discussion of addiction as a disability, see Reese J. Henderson Jr., Addiction As Disability: The Protection of Alcoholics and Drug Addicts Under the Americans with Disabilitics Act of 1990, 44 VAND. L. REV. 713 (1991).

102. This certification would be particularly troublesome due to the vast array of techniques that are available to smokers who want to quit. Studies show that desire is a key component to the success of all these techniques, yet smokers seeking only to be certified as addicted might not earnestly participate. See Lee \& D'Alonzo, supra note 37, at $38-45$.

103. See U.S. DeP'T OF Health \& HuM. ServS., The Health Benefits of SMOKING CESSATION xii (1990); supra note 67.

104. 42 U.S.C. $\S 12102(2)(A)$ (Supp. III 1991). 
forming manual tasks, walking, seeing, hearing, speaking, breathing, learning and working." ${ }^{\text {105 }}$ It is unclear exactly what constitutes a substantial limitation under the $\mathrm{ADA},{ }^{106}$ but this language mirrors section 504 of the Rehabilitation Act. The Equal Einployment Opportunity Coinmission (EEOC) has stated that the caselaw interpreting section 504 is relevant to construing the parallel provisions of the ADA. ${ }^{107}$

Courts have struggled to find a definitive test of what constitutes a substantial limitation under section 504. In Jasany v. United States Postal Service, ${ }^{108}$ the Sixth Circuit held that the plaintiff, who was cross-eyed, was not substantially limited because the impairment affected only a narrow range of jobs. ${ }^{109}$. In 1986 , the Fourth Circuit observed that deterinining who is handicapped "cannot be accomplished merely through abstract lists and categories of impairments" but must be examined on a case-by-case basis, taking into account whether the "particular impairment constitutes for the particular person a significant barrier to eniployment." 110

Although sinoking has been shown to contribute substantially to a variety of respiratory and cardiac problems, the addiction itself does not impair any major life activities as defined by the ADA. ${ }^{111}$ Even the shortness of breath that sinokers generally experience is not enough to interfere with most activities, including working. The committee reports on the ADA indicate that courts should consider whether important life activities "are restricted as to the conditions, manner or duration under which they can be performed in comparison to most people."112 The EEOC regula-

105. See H.R. REP. No. 485, 101st Cong., 2d Sess. 28 (1990), reprinted in 1990 U.S.C.C.A.N. 267, 451.

106. See id. at 334; 45 C.F.R. $\S 84$ app. A, subpt. 3 (1992) (appendix to the regulations implementing $\$ 504$ of the Rehabilitation Act) (stating that a definition of the term is not currently possible); see also Henderson, supra note 101, at 718 (pointing out that courts have struggled with the "substantially limits" requirement in the Rehabilitation Act).

107. See 29 C.F.R. 1630.1(c)(2) (1993); see also supra note 77.

108. 755 F.2d 1244 (6th Cir. 1985).

109. Id. at 1250 .

110. Forrisi v. Bowen, 794 F.2d 931, 933 (4th Cir. 1986).

111. Smoking-induced respiratory or cardiac diseases clearly would qualify as disabilities under the ADA, but nicotine addiction, in and of itself, would not be a basis for coverage. See H.R. REP. No. 485, 101st Cong., 2d Sess. 51-52 (1990), reprinted in 1990 U.S.C.C.A.N. 267, 333-34.

112. Id. at 334 . 
tions implemented to enforce the ADA state that "substantially limits" means

significantly restricted in the ability to perform either a class of jobs or a broad range of jobs in various classes as compared to the average person having comparable traiming, skills and abilities. The inability to perform a single, particular job does not constitute a substantial limitation in the major life activity of working. ${ }^{113}$

This issue was addressed in Harmer v. Virginia Electric \& Power Co. ${ }^{114}$ one of the first reported cases to construe the ADA provisions. The court held that the plaintiff's good performance appraisals were evidence that his performance of the essential functions of his job was comparable to that of other employees, so that his bronchial asthma, although qualifying as a disability, was not sufficient to entitle him to protection under the ADA. ${ }^{115}$ Similarly, millions of smokers function normally in society and in the workplace despite their habit, and are not restricted in their ability to perform a broad range of jobs. Thus, nicotme addiction should not qualify as a disability under the ADA.

Courts also might exclude smoking from coverage under the definition of disability because those who smoke generally choose to do so knowing the risks and problems associated with it. ${ }^{116}$ The element of choice involved in taking up smoking is significant because under the Rehabilitation Act some federal courts refused to classify as handicaps ${ }^{117}$ conditions that are not immutable ${ }^{118}$

113. 29 C.F.R. § 1630.2(j)(3)(i) (1993); see also E.E. Black, Ltd. v. Marshall, 497 F. Supp. 1088, 1099 (D. Haw. 1980) (holding that the inability to perform a particular job does not render a person handicapped and that the perceived handicap must substantially limit a person's ability to find work in his chosen field).

114. 831 F. Supp. 1300 (E.D. Va. 1993).

115. Id. at 1306 .

116. Alcoholism may be considered voluntary as well, although there are a variety of other factors that also may contribute to one's propensity to become an alcoholic. See Traynor v. Turnage, 485 U.S. 535, 549-50 (1988) (describing such other factors); infra notes 131-36 and accompanying text.

117. "Handicapped" is a term of art in the Rehabilitation Act. The drafters of the ADA opted to use the term "disabled" instead, in an effort to use "terminology most in line with the sensibilities of most Americans with disabilities.” H.R. REP. No. 485, 101st Cong., 2d Sess. 51 (1990), reprinted in 1990 U.S.C.C.A.N. 267, 333.

118. See, e.g., Greene v. Union Pac. R.R., 548 F. Supp. 3, 5 (W.D. Wash. 1981) (holding that obesity does not qualify as a handicap under Washington's anti-discrimination statute because it is not immutable, as are "blindness or lameness"). 
or are caused by activities that were self-imposed or voluntary. ${ }^{119}$ Courts are likely to extend this reasoning to the ADA.

A disabihity also is defined in terms of the perceptions of others. The ADA covers people who may be "regarded as" disabled who actually are not substantially limited in any major life activities, except by the attitudes of others. ${ }^{120}$ For example, the legislative history of the ADA shows that burn victims are frequently viewed as disabled and discriminated against, although they may not be functionally disabled at all. ${ }^{121}$ Under this test, such an individual would clearly be covered by the ADA.

The U.S. Supreme Court, construing the Rehabilitation Act, created the "regarded as" test in School Board v. Arline. ${ }^{122}$ In Arline, the Court stated that because the plaintiff's tuberculosis was perceived to be contagious she merited protection under the Rehabilitation Act to prevent "discrimination on the basis of mythology." 23 The Court reasoned that "[s]uch an impairment might not diminish a person's physical or mental capabilities, but could nevertheless substantially limit that person's ability to work as a result of the negative reactions of others to the impairment." ${ }^{24}$ The Court emphasized that, although an individual may not be actually disabled, the negative perceptions and reactions of others may be just as disabling.

Because Congress explicitly incorporated Arline's "regarded as" test into the definition of disability under the ADA, applications of this subjective standard under the Rehabilitation Act are helpful in determining the scope of the meaning of disability under the ADA. ${ }^{125}$ For example, in Forrisi $v$. Bowen, ${ }^{126}$ the Fourth Circuit held that a utility systems repairer who suffered from acro-

119. See, e.g., Tudyman v. United Airlines, 608 F. Supp. 739, 746 (C.D. Cal. 1984). The analogy of discrimination against obese people has some utility in this context. For a more complete discussion of the treatment of obesity under the discrimination laws, see Robin Chodak, Recent Decisions, 65 TEMP. L. REv. 623 (1992).

120. See H.R. REP. No. 485, 101st Cong., 2d Sess. 53 (1990), reprinted in 1990 U.S.C.C.A.N. 267, 335.

121. Id.

122. 480 U.S. 273 (1987).

123. Id. at 285 .

124. Id. at 283 .

125. See 42 U.S.C. \& 12102(2)(c) (Supp. III 1991); see also Alexander v. Choate, 469 U.S. 287, 299 (1985) (stating that interpretations of the Rehabilitation Act should be responsive to two countervailing considerations: to effectuate the statutory objectives and to keep the scope of its coverage within manageable bounds).

126. 794 F.2d 931 (4th Cir. 1986). 
phobia was not handicapped simply because he was unable to perform a particular job. Rather, he had to show that his perceived impairment foreclosed that entire type of employment. ${ }^{127}$ By analogy, even if smokers were regarded as unable to perform extremely strenuous tasks, that perception would not be enough to bring them under the rubric of the ADA as long as there were other, less strenuous jobs available withm the same type of employment.

According to the legislative history, this definition of disability was intended to compensate for society's accumulated myths, fears, and stereotypes of disabilities. ${ }^{128}$ Although it is difficult to determine what these are with respect to smokers, the reasons employers often give for not hiring smokers are generally supported by a vast array of scientific studies and surveys. ${ }^{129}$ The Supreme Court in Arline stated that the "regarded as" test is "carefully structured to replace such reflexive reactions ... . with actions based on reasoned and medically sound judgments." ${ }^{130}$ Consequently, employers who adopt hiring policies that discriminate against smokers are well advised to articulate their rationales for these decisions carefully, making it clear that they are not based on negative attitudes, fears, or stereotypes. Policies based on careful cost-benefit analyses and supported by sound scientific studies are far more likely to withstand judicial scrutiny under this definition.

Some commentators argue that smoking is analogous to alcoholism, which is explicitly covered under the ADA. ${ }^{131}$ Drinking, like smoking, is a habit that is voluntarily undertaken and addictive. ${ }^{132}$ Beyond that, however, the analogy breaks down. Studies have shown that a variety of genetic and sociological factors may

127. Id. at 935; see also Tudyman v. United Airlines, 608 F. Supp. 739, 746 (C.D. Cal. 1984); E.E. Black, Ltd. v. Marshall, 497 F. Supp. 1088, 1099 (D. Haw. 1980).

128. See H.R. REP. No. 485, 101st Cong., 2d Sess. 30-31 (1990), reprinted in 1990 U.S.C.C.A.N. $267,452-53$.

129. See supra Sections I(A)-(B).

130. School Bd. v. Arline, 480 U.S. 273, 285 (1987).

131. See, e.g., Goh, supra note 73 , at 833 .

132. Id. This assertion is not without controversy. The debate is nicely illustrated in Traynor v. Turnage, 485 U.S. 535, 549-50 (1988), in which the Court discussed the question of whether alcoholism was a disease or the result of willful misconduct. For a complete discussion of alcoholism and the ADA, see Wendy $\mathrm{K}$. Voss, Note, Employing the Alcoholic Under the Americans with Disabilities Act of 1990, 33 WM. \& MARY L. REv. 895 (1992). 
contribute to a person's propensity to become an alcoholic; ${ }^{133}$ no such effect has been shown with respect to nicotine addiction.

The effects of these addictions within the workplace are quite different as well. Drinking alcohol on breaks or during lunch would be unacceptable if it interfered with the einployee's performance on the job, and eniployers are free to prohibit alcoholic employees from drinking during work hours. ${ }^{134}$ More iniportantly, an alcoholic's illness is nuch more likely to interfere substantially with his conduct on the job ${ }^{135}$ and can be dangerous, for exantple, when heavy machinery is involved. Because the pharmacological effects of nicotine are not nearly as debilitating as those of alcohol, snokers often smoke while working. Unlike alcoholism, however, snioking can pose a significant health threat to other eniployees who are merely working in the sanie airspace. ${ }^{136} \mathrm{Be}-$ cause the problenis associated with employing sniokers and alcoholics are different, employers must find different approaches for solving them.

\section{Application of the ADA's Defenses}

If courts hold that sniokers are covered under the ADA, employers with exclusively nonsmoking hiring policies may still find protection under the defenses provided in Title $I$ of the ADA. There are two important defenses to discrininatory practices under the Act. First, the eniployer may forego the accomniodation if it places an "undue hardship" on the company. ${ }^{137}$ The availability of this defense depends on factors such as the size, financial resources, and operation of the business, as well as the nature and cost of the accommodation. ${ }^{138}$ In some cases, the plaintiff may overconie this defense by showing that funding is available from federal, state, or private sources. ${ }^{139}$

133. See Traynor, 485 U.S. at 562-64 (citing studies on the genetic and cultural causes of alcoholism).

134. See 42 U.S.C. $\S 12114$ (c) (Supp. III 1991).

135. The ADA does allow employers to prohibit on-the-job use of alcohol and to hold alcoholics to the same performance standards as other employees. See 42 U.S.C. \& 12114(c) (Supp. III 1991).

136. See supra notes $37-40$ and accompanying text.

137. 42 U.S.C. $\S \S 12111(10), 12112(b)(5)(A)$ (Supp. III 1991).

138. Id.; see also H.R. REP. No. 485, 101st Cong., 2d Sess. 35 (1990), reprinted in 1990 U.S.C.C.A.N. 267, 457.

139. See Stine, supra note 87, at 105. 
A second defense is available if the employer can show that a disabled imdividual poses a direct threat to the health and safety of other employees. ${ }^{140}$ The ADA defines a "direct threat" as "a significant risk to the health or safety of others that cannot be eliminated by reasonable accommodation."141 Under the EEOC's regulations, factors such as the nature and duration of the risk and the likelihood and imminence of the potential harm are relevant to the defense. ${ }^{142}$

In the case of smoking in the workplace, these defenses are inextricably intertwined because of employers' simultaneous duties to accommodate an inherently dangerous habit and to protect the rest of the workforce from the dangers of ETS. Employers are placed in the unenviable position of having to balance smokers' interests against those of the rest of the workforce. We now know that environmental tobacco smoke poses a serious health threat to all einployees, ${ }^{143}$ and some workers may be hypersensitive to tobacco smoke-a disability that itself may require the reasonable accommodation of a sinoke-free working environment. ${ }^{144}$ For employers, the costs of accommodating addicted sinokers while preserving a safe, sinoke-free working environment for other employees may impose an undue hardship.

1. Reasonable Accommodations for Addicted Smokers. It is unclear what reasonably accommodating a nicotine addict would entail. The legislative history of the ADA suggests that the employer must take steps to ensure that the disabled person will be able to perform the essential functions of his job. ${ }^{145}$ This accommodation may include job restructuring, part-time or modified work schedules, or other accommodations, depending on the needs

140. 42 U.S.C. $\S 12113(b)$ (Supp. III 1991). For a more complete discussion of this defense, see Mary A. Sedey, The Threat to Safety Defense Under the Americans with Disabilities Act: Its Source, Surrounding Caselaw, and Interpretation, 39 FED. B. NEws \& J. 96 (1992).

141. 42 U.S.C. $\S 12111(3)$ (Supp. III 1991).

142. See 29 C.F.R. $\S 1630.15$ (b)(2) (1993).

143. See supra notes $37-40$ and accompanying text.

144. See generally Vickers v. Veterans Admin., 549 F. Supp. 85, 87 (W.D. Wash. 1982) (holding that an employee who was hypersensitive to tobacco smoke was handicapped under the Rehabilitation Act); supra notes 49-51 and accompanying text.

145. H.R. REP. No. 485, 101st Cong., 2d Sess. 57 (1990), reprinted in 1990 U.S.C.C.A.N. 267, 339. 
of the employee. ${ }^{146}$ Employers could conceivably work with smokers to provide more frequent breaks or an office with a separate air recirculation system. Some addicts may be able to use transdermal nicotine patches or incotine gum at work. Forcing employees to leave the building to sinoke may be reasonable depending on the distance and weather conditions they would be obliged to endure. Thus, the required effort at accommodation will inevitably vary depending on the needs of the addicted smoker and the financial resources and adaptability of the employer.

2. The Scope of the Undue Hardship and Direct Threat Defenses. The ADA provides that an employer does not need to comply with its provisions if the accoinmodation presents an undue liardship. ${ }^{147}$ The determination of undue hardship is made on a case-by-case basis, taking into account the size and financial resources of the business, ${ }^{148}$ the type of operations it maintains, and the nature and cost of the accommodation required. ${ }^{149}$ The burden is on the einployer to show that the accommodation presents an undue hardship, but the employee has an opportunity to show that his disability may be accominodated in a less burdensome manner. ${ }^{150}$ Significantly, the regulations emphasize that the defense is not limited to financial difficulties but also is available if the accommodation would be "unduly ... extensive, substantial, or disruptive, or [if it] would fundainentally alter the nature or operation of the business."151

In the smoking context, the undue hardship defense will be more readily available to sinall coinpanies with fewer financial resources, due to the potential costs of accommodating smokers in the workforce. Larger corporations may still prevail by claiming that it would be unduly disruptive to build separate facilities for smokers or to allow them to take more breaks. The defense is also available if the employer can slow that accommodating the smoker would be detrimental to the ability of other employees to

146. Id.

147. 42 U.S.C. \& 12112(b)(5)(A) (Supp. III 1991).

148. This determination will take into account the number of employees, the number, size, and location of facilities, and the financial resources of the business. See H.R. REP. No. 485, 101st Cong., 2d Sess. 67 (1990), reprinted in 1990 U.S.C.C.A.N. 267, 349.

149. Id.

150. 29 C.F.R. $\S 1630.15(\mathrm{~d})$ (1993).

151. Id. $\$ 1630.2(\mathrm{p})$ (app.) (citation omitted). 
perform their duties or to the company's ability to conduct business. ${ }^{152}$

The direct threat defense likely will be available when employees are working with substances that work synergistically with tobacco smoke. ${ }^{153}$ Whether the dangers of ETS to other employees are sufficient to support this defense is not clear because these dangers can be eliminated through accommodations that may be escapable under the undue hardship defense.

\section{CONCLUSION}

To include micotine addicts among the ranks of the disabled would lead to a variety of unpleasant policy implications. Although it is unclear how many of America's 48.5 million smokers could qualify as addicted, ${ }^{154}$ including them as a protected class could vastly increase the number of clains filed with the EEOC, which is statutorily required to review all claims. ${ }^{155}$ This potential growth in the number of filings could exacerbate the EEOC's backlog to such an extent that other Ainericans with more severe disabilities would face long delays in the processing of their claims.

Employers who want to implement workplace smoking restrictions for the protection of nonsmoking workers may find the financial and admimistrative burdens of accommodating protected smokers and defending potential lawsuits too excessive to warrant any new policy. In addition, there are a variety of government and public grants available to employers who hire individuals with disabilities to help them pay for necessary accommodations. Defining smokers as disabled might mean that these funds could be accessed by them, leaving fewer resources to purchase aids for other disabled individuals, such as telephone amplifiers for the hearing impaired or adaptive computer software for the blind.

Even the addicted smoker should not be considered to be im the same category as a permanently physically disabled individual. Unlike blimdness, multiple sclerosis, cerebral palsy, and other perInanent disabilities, the smoker can, with effort, overcome his disability. There are numerous programs and pharmaceutical products available to help smokers quit for a relatively small cost com-

152. See id:; Stine, supra note 87 , at 104.

153. See supra notes $28-31$ and accompanying text.

154. See supra notes 100-36 and accompanying text.

155. See 42 U.S.C. § 12117(a) (Supp. III 1991). 
pared to the future health costs they are likely to incur. It would be manifestly unjust for the millions of smokers in America to usurp valuable employer and government resources that could be used to give an otherwise unemployable disabled person a job. On the other hand, allowing einployers to discriminate against smokers in hiring decisions would create a clear and immediate inducement for them to seek help on their own. This approach would allow market forces to eventually solve the problem without any government intervention. Unike individuals who have been permanently disabled by accidents, diseases, or birth defects, smokers retain the ability to seek help and overcome their habit.

The Americans with Disabilities Act is a promising means for millions of disabled Americans to overcome the barriers that society has placed before them. Meanwhile, smoking causes inore premature deaths than cocaine, heroine, alcohol, fire, automobile accidents, homicide, and suicide combined. ${ }^{156}$ It would be truly unfortunate if a landmark statute, passed to remedy discrimination against millions of capable disabled people, were distorted to slow progress toward the elimination of this dangerous and expensive habit froin the American workplace.

156. SMOKING AND HEALTH, supra note 1 , at 8. 